\title{
The Role of Schools of Public Health in the COVID-19 Pandemic
}

\author{
John Middleton ${ }^{\mathrm{a}}$ \\ ${ }^{a}$ Association of Schools of Public Health in the European Region (ASPHER), UM Campus Brussels, Brussels, Belgium
}

The COVID-19 pandemic has been catastrophic for the health and livelihoods of people all over the planet. Over a year on, there is still no prospect of an ending to the pandemic. There is little evidence of coherent international commitment and consensus on a strategy to suppress viral transmission and chart a global route out of the pandemic. As I write, the world has recorded 115 million cases and 2.5 million deaths. The Association of Schools of Public Health in the European Region (ASPHER) has been active in supporting our members' work combatting the pandemic since early March 2020 [1]. Our active members in Portugal have contributed with major papers on the use of masks [2,3], the limitations of testing [4-6], planning for a second wave [7], children's masks [8], and the spread of the virus in meat plants [9]. These papers are among the output of the ASPHER COVID-19 task force [10] and have influenced the policy positions of national governments and international agencies such as the WHO Europe, the Global Network of Academic Public Health (GNAPH) [11], the European Centre for Disease Prevention and Control (ECDC), and other European health partners.

National governments and public health leaders have been found unprepared and indecisive in many parts of the world. Public health systems and services have been cut back over many years prior to the pandemic and it will be one of our tasks to rebuild and attract new investment into training, research, and professional capacity building for the protection and improvement of the public's health [1]. ASPHER is at the forefront of campaigning for these. Our paper on the erosion of public health has been published now [12] and our extensive report on the actions of schools of public health can be viewed on our website [13].

If anything should demonstrate the need for public health systems and services it is this pandemic. Many countries have lacked professional resources to respond to the outbreak. We have also been slow to document the harmful social and economic effects arising through the lockdowns which have been needed to control the virus [14]. We need public health resources, and policies, to tackle the inequalities in our societies, which make the pandemic deadlier to some groups and communities. Pandemic diseases of poverty, mass overconsumption, and addiction have also created a foundation upon which the virus can have a deadlier impact $[14,15]$.

The scientific community has struggled to gather the collective memory hidden in the literature of a bygone era to rediscover the lessons of the 1918 Spanish flu pandemic [16]. For example, in the Western world we have had to relearn the use of masks for protection of the wider community [17]. We have also uncovered economic and social evidence from 1918 showing the effects of early and prolonged lockdowns to enable earlier economic recov- (c) 2021 The Author(s). Published by S. Karger AG, Basel on behalf of NOVA National School of Public Health

This is an Open Access article licensed under the Creative Commons Attribution-NonCommercial-4.0 International License (CC BY-NC) (http://www.karger.com/Services/OpenAccessLicense), applicable to the online version of the article only. Usage and distribution for commercial purposes requires written permission.
Correspondence to:

John Middleton, john.middleton@ aspher.org 
ery [18]. Much of our knowledge of plagues and pandemics has been the preserve of medical historians and felt to be a distant novelty rather than a fearful reality [19]. The 21 st century is likely to be the century of pandemics [20]. We seek to maintain our destructive levels of international travel, which microorganisms also enjoy. We destroy progressively more natural environments and interrupt ecosystems, exposing ourselves to more novel zoonotic pathogens. We create poverty, inequality, insecurity, migration, and conflict, forcing human beings together in overcrowded, insanitary, dangerous conditions. Human ageing and infirmity, and our poor health-related behaviors, leave us more at risk of the most harmful effects of infectious diseases, as we have seen so starkly in this pandemic.

Our responsibility today is to document as fully as we can the effects of the SARS-COV2 virus and the effects of the COVID-19 pandemic. This collection of papers from the Portuguese experience, mainly in the first wave, highlights important issues we must all learn from, i.e., the epidemiological characteristics of the spread of infection and impacts on hospitalization, the impacts on healthcare and the role of screening of health care workers, and the impacts of lockdown including the appalling consequence of domestic violence. There is recognition of the need to engage the public, to understand their feelings and perceptions, and to repeat this regularly. There must be consent and trust between politicians, professionals, and the people we serve [7]. This will not be the only word on the Portuguese experience, and it will not be the last word. The second wave has had devastating effects on the people of Portugal, and ASPHER stands in solidarity with you all [21]. There will be much new knowledge for us all to learn from, and I look forward to reading further highquality reports from the outstanding public health community in Portugal.

I commend this suite of papers as a vital contribution bearing witness to some of the experience of this pandemic in Portugal. The experience within different countries and comparisons between countries are an essential means by which we can learn from each other and help us to prepare better for the pandemics of the future.

\section{References}

1 Middleton J, Martin-Moreno JM, Barros H, Chambaud L, Signorelli C. ASPHER statement on the novel coronavirus disease (COVID-19) outbreak emergency [Internet]. Int J Public Health. 2020 Apr;65(3):237-8. [cited 2020 Mar 30] Available from: https://www. aspher.org/aspher-covid19-statement-signatories.html.

2 Middleton J, Lopes H. ASPHER statement on the strategic use of masks [Internet]. Brussels: ASPHER; 2020[cited 2020 Mar 30]. Available from: https://www.aspher.org/aspher-statement-masks.html.

3 Middleton J, Lopes H; ASPHER COVID-19 task force. Statement on the new recommendations for the use of masks following the spread of SARS-CoV-2 variants: January 29th, 2021. [Internet]. Brussels: ASPHER; 2021 [cited $2021 \mathrm{Feb}$ 2]. Available from: https://www.aspher.org/download/636/ statement_on_the_new_recommendations_ for_the_use_of_masks_following_the spread_of_sars-cov-2-variants.pdf.

4 Pinto da Costa J. Barros H, Middleton J. ASPHER statement on COVID-19 testing: May 4th, 2020. Brussels: ASPHER; 2020. [cited 2020 May 11]. Available from: https:// www.aspher.org/download/421/aspher statement_on_the_covid-19_testing.pdf.
5 Pinto da Costa J, Barros H, Middleton J, Mason-Jones A, Fernandez A, Signorelli C, et al. COVID-19 testing: a reflection on test accuracy in the real world. Brussels: ASPHER; 2020 [cited 2020 May 11]. Available from: https://www.aspher.org/download/420/covid-19_testing_a_reflection_on_test_accuracy_in_the_real_world.pdf.

6 Pinto da Costa J, Barros H, Sheek-Hussein M, Prikazsky V, Kostoulas P. COVID-19 testing from a public health perspective: selection of test, cut-off and sampling scheme should depend on the purpose of testing: second ASPHER statement on testing: January 2021. Brussels: ASPHER; 2021. [cited 2021 Mar 5]. Available from https://www.aspher.org/ download/635/covid-19_testing_from_a_ ph_perspective.pdf

7 Middleton J, Lopes H, Michelson K, Reid J. Planning for a second wave pandemic of COVID-19 and planning for winter: A statement from the Association of Schools of Public Health in the European Region. Int J Public Health. 2020 Dec;65(9):1525-7.

8 Lopes H, Middleton J, De Guchtenaere A, Hadjipanayis A. Statement from the Association of Schools of Public Health in the European Region and the European Academy of Paediatrics: COVID-19 and the use of masks by children. Front Pediatr. 2021 Jan;9:580150.

9 Middleton J, Reintjes R, Lopes H. Meat plants-a new front line in the COVID-19 pandemic. BMJ. 2020 Jul;370:m2716.
10 Association of Schools of Public Health in the European Region. ASPHER COVID-19 task force website [Internet]. Brussels: ASPHER; 2021 [cited 2021 Mar 5]. Available from: https://www.aspher.org/covid-19-task-force. html.

11 ASPHER. Global Network for Academic Public Health Network launch: May 2020 [Internet]. Brussels: ASPHER; 2021 [cited $2021 \mathrm{Mar}$ 5]. Available from: https://www.aspher.org/ global-network-for-academic-public-health. html.

12 Wong B, et al. The erosion of public health Public Health Rev. 2021. Available at: https:// www.ssph-journal.org/articles/10.3389/ phrs.2021.1604112/full.

13 Bauernfeind A, Foldspang A, Fernandez A, Otok R, Middleton J. The role of European schools of and university departments of public health in the 2020 COVID-19 response: an ASPHER survey [Internet]. Brussels: ASPHER; 2021 [cited $2021 \mathrm{Mar} 5$ ]. Available from: https://www.aspher.org/download/663/aspher-survey-report-role-of-sphscovid-19-response.pdf. 
14 Prajapati N, Łaszewska A, Franco D, Ericson $\mathrm{R}$, Leroy S, Lindert J, et al. What are the COVID-19 lockdown-induced illnesses and why should European public health systems be investigating their epidemiology, treatment, and prevention? Report of the ASPHER COVID-19 Task Group [Internet]. Brussels: ASPHER COVID-19 Task Force; 2020 [cited 2021 Mar 5]. Available from: https://www. aspher.org/download/531/aspher-lockdowninduced-illnesses.pdf.

15 ASPHER. First statement of the ASPHER COVID-19 Task Group on Health Inequalities and Vulnerable Populations: COVID-19: how and why is the pandemic exacerbating and amplifying health inequalities and vulnerabilities in Europe? [Internet]. Brussels: ASPHER; 2021 [cited 2021 Mar 5]. Available from: https://www.aspher.org/download/428/aspher-covid-19-task-force-firststatement-on-health-inequalities-and-vulnerable-populations.pdf.
16 US Department of Health and Human Services; CDC. 1918 pandemic (H1N1 virus) [Internet]. Atlanta: CDC; 2021 [cited $2021 \mathrm{Mar}$ 5]. Available from: https://www.cdc.gov/flu/ pandemic-resources/1918-pandemic-h1n1. html.

17 Hauser C. The mask slackers of 1918 [Internet]. New York Times. 2020 Aug 3 [cited 2021 Mar 5]. Available from: https://www.nytimes. com/2020/08/03/us/mask-protests-1918. html.

18 Hatchett RJ, Mecher CE, Lipsitch M. Public health interventions and epidemic intensity during the 1918 influenza pandemic. Proc Natl Acad Sci USA. 2007 May;104(18):75827.
19 Pollock G. Fevers and cultures: lessons for surveillance, prevention, and control. Oxford: Radcliffe Medical Press; 2003.

20 Inter-governmental Panel on Biodiversity and Ecosystem Services (IPBES). Pandemics report: scaling the era of pandemics. Bonn: IPBES Secretariat; 2020. Available at: https:// www.ipbes.net/pandemics.

21 Chatarajupalli P, Reintjes R, Middleton J. ASPHER report: COVID-19 situation reporting across Europe - week of January 25th, 2021 [Internet]. Brussels: ASPHER; 2021 [cited 2021 Mar 5]. Available from: https://www.aspher.org/download/640/ aspher_covid-19_situation_reporting_25_01_21.pdf. 